\title{
Native and Non-native English Teachers' Classroom Ideologies and its Implementation in ESL Classroom
}

Hema Vanita Kesevan*, Noor Alhusna Madzlan, Kaaminy Kanapathy

Faculty of Languages and Communication, Sultan Idris Education University, 35900, Tanjong Malim, Malaysia

Corresponding Author: Hema Vanita Kesevan, E-mail: hemakesevan@fbk.upsi.edu.my

\section{ARTICLE INFO}

Article history

Received: July 08, 2018

Accepted: September 28, 2018

Published: December 01, 2018

Volume: 7 Issue: 7

Advance access: October 2018

Special Issue on Language \&

Literature

Conflicts of interest: None

Funding: The research is financed by

Research Management and Innova-

tion Centre of Sultan Idris Education

University under the GPU grant.

No. 2016-0195-106-012006.

\begin{abstract}
The global spread of English language has led many classrooms in the post-colonial contexts that teach English as a second and foreign language to pursue a perpetual belief that native English teachers have different teaching ideologies and practices compared to non-native teachers. Although teachers' ideologies are deemed to be influential in shaping their classroom pedagogical practices, not many studies have examined teachers' ideologies and its actual implementation in classroom pedagogical practices. Many past studies in this area have focused either on teachers' classroom beliefs or classroom practices. Thus far, there is no any empirical evidence that supports the existing belief that native and non-native English teachers pursue different teaching ideologies and practices. Thus, this study seeks to understand whether as suggested, the native and non-native English teachers pursue different teaching ideologies and practices in Malaysian ESL classroom context. This study provides insights and empirical evidences into teaching ideologies and actual classroom pedagogical practices of teachers in Malaysian ESL classroom context.
\end{abstract}

Key words: Native English Teachers, Malaysian Teachers, ESL Classrooms

\section{INTRODUCTION}

Increasingly, as globalisation and English continue to bring people of different cultures and linguistic backgrounds together through the form of English communication, it has further entrenched the distinction between so-called native and non-native speakers (Jenkins, 2005). In the field of English language education, native teachers are very often regarded as superior and the supposed 'ideal' language model over the non-native teachers. Although native teachers have not been empirically and conclusively established as superior to the non-native teachers (Nayar, 1998), the perception that the former is a 'better' teacher continues to hold sway in many English as a Second Language (ESL) and English as a Foreign Language (EFL) classroom settings. While there is little empirical research on the issue, the few studies that exist suggest that native and non-native teachers differ in target language competence, teaching behaviour, and approach due to differences in their linguistic competence (Arva and Medgyes, 2000). Non-native teachers are reported to favour isolated practice of linguistic elements while the native teachers are reported to prefer an integrated approach (Reves and Medgyes, 1994). Another study that investigated the teachers' teaching approaches suggested that the native teachers practice modern and communicative way of teaching in comparison to their non-Western counterparts (Barrios, 2002). In the case of countries like Malaysia, we know little about teachers' actual teaching practices in the ESL classroom contexts and how the teachers' teaching practices correlate with their teaching ideologies. Studies that have explored expatriate native and local non-native teachers' practices in Malaysian language classrooms have only focused on teachers' teaching beliefs (Farimah \& Fatimah, 2013; Fathen et. al, 2013) and the sociolinguistics background of the teachers (Gibson \& Swan, 2008). This study, in contrast, aims to examine common assumptions regarding the classroom ideologies of native and non-native teachers and its actual implementation in classroom practices. The main two objectives of this study are; to explore the classroom ideologies of native and non-native teachers in the Malaysian ESL teaching context and to compare their ideologies and its actual implementation in classroom practices, with a view to explore how ideologies mediate in their actual practices and what influences the different ideologies and practices among native and non-native English teachers.

Do the native ETA and non-native Malaysian English teachers pursue different teaching ideologies and practices.

\section{Classroom Ideologies and Pedagogical Practices}

Ideology refers to belief systems. It is a form of belief or societal structure which influences our practices. This system is 
shared by members of a group or society rather than being a feature of a single individual. This does not, however, mean that a certain ideology is necessarily shared by all members of a society or group. In fact, members of the same society may have competing sets of beliefs. For example, teachers in the same educational system may have different views about pedagogical practices. Ideology functions to organise and control other socially shared beliefs and associated actions (Eagleton, 1991). For instance, an educational ideology may shape and control beliefs about a teaching style, including student participation, types of activities, seating arrangements, and other classroom related matters. These views in turn guide people's actions in these contexts. Ideologies are world views that an individual, group, or society holds to be important or true, these views are shared by a society and form the basis for how it should function (Schieffelin, 1998).

The term language ideologies in classroom studies tries to capture "the implicit, usually unconscious assumptions about language and language behaviour that fundamentally determine how human beings interpret events" (Tsui \& Tollefson, 2007:26). Language ideologies are rooted in the social practices of people. It does not only refer to people's ideas, notions, or representations of language, but also to the practices through which they are enacted (Kroskrity, 2010). That is, when people are engaged in language practices such as classroom instruction, they are simultaneously displaying their beliefs about the nature, function, and purpose of language use. Language ideology postulates that there is an inextricable link between language use and the broader historical and institutional practices, values, and interests (ibid, 2010). Traditionally, research on language attitudes in education tends to explore an individual's beliefs, but pays less attention to shared beliefs and politics of language as in the case of language ideologies. Research on language ideologies, variously referred to as language ideology, linguistic ideologies, or ideologies of language, investigates how speakers rationalise their language use, including linguistic forms and discursive practices (Kroskrity, 2010).

The review of language classroom research that focused on teachers' effectiveness and pedagogical decisions in Malaysia demonstrated that a large number of studies (Liao, 2007; Farahian \& Rezaee, 2012; Kaanta, 2012; Jerome \& Samuel, 2014) used the teacher ideology perspective to investigate teachers' beliefs. However, only a very small number of studies involved the study of both teachers' actual classroom practices and the relationships between teacher ideology and actual classroom practices. The studies conducted in Malaysian language classrooms found that knowledge and ideologies about pedagogy are complex, and that they influence teachers' instructional practices and shape their decisions in relation to these practices (see Jerome \& Samuel, 2014). The limited number of studies that have explored both teachers' ideology and actual practice in the Malaysian language classroom context reported that teachers were inclined to converge and diverge in their practices based on their beliefs for several reasons. For instance, Wing (2012) reported that, in her study, pre-school teachers not only implemented their pedagogical beliefs in their practices, but also acknowledged the beliefs that shaped their practices. In contrary, a study conducted by Samad \& Nurusus (2015) in secondary schools which investigated teachers' ideology and practice of grammar teaching, revealed that a great majority of the teachers diverged from their beliefs. The study further identified learners' proficiency and the school location as crucial factors that influenced the divergence of the teachers' practice from their beliefs. It suggests that language classrooms situated in rural areas have an impact on the teachers' practice as the learners' have limited language proficiency, and in the event that less experienced teachers are placed in this situation, they struggled to modify their beliefs to suit the learners' needs. Although these teachers' practice was closely aligned with their ideologies, they were not flexible enough to adjust their ideologies in order to meet the learners' learning requirements. In comparison, the experienced teachers in the same settings were reported to diverge from their ideologies, however, the divergence in their practice was to accommodate to the learners' needs.

Based on the review of past studies in language classrooms, it is apparent that there is a complex relationship between teachers' ideologies and pedagogical practices. The ideologies held by the teachers are reflected in various aspects of classroom practices, such as teaching styles, classroom instructions, discourse practices, along with other instructional practices. The classroom ideologies of all teachers are not necessarily the same as each teacher's ideologies are formed based on various aspects (Borg, 2003).

\section{METHODOLOGY}

In order to investigate the native and native teachers' actual teaching practices and ideologies, data were collected from three groups of participants. The first group consists of four local Malaysian English teachers, the second group is four English teacher assistants (ETA) from native speaking countries and the third group consists of 150 students from both of the teachers' classroom. The teachers are from various rural schools located in the district of Perak. The local Malaysian teachers are trained locally in Malaysian universities and have been teaching for a duration of 4-8 years. Meanwhile the native English teacher assistants come from United States of America, some of them have teaching experience from various Asean countries however all the native English teachers assistance are not trained in the field of teacher training. Both of these teachers co-teaches in same classrooms to the same group of students. The students involved in this study are Form 3 students who have been taught by both of these groups of teachers for about three years. They are familiar with the classroom and pedagogical practices of both types of teachers.

As this study focuses to explore the teachers' ideologies and actual teaching practices from the lens of students' perspectives, two types of data were collected from the participants. Interview data were gathered from the teacher participants and questionnaire responses were gathered from the students. The former explores the teachers' ideological stance from four aspects; questioning, providing feedback, wait time after questioning and teaching approaches. The later investigates students' perspectives on the actual 
implementation of the four aspects by the teachers in the classroom practices. The two types of data were compared for the convergence and divergence of the teachers' ideologies in actual implementation.

This study uses a mixed method approach to analyze the two types of data. The interview data obtained from the teachers were analysed qualitatively using Kroskrity's language ideology concept. The interview data was first analysed to gain an insight into the teachers' classroom ideologies and rationalizations. Once the teachers' ideologies have been identified, it compares their ideologies in order to determine the differences of beliefs between the two types of teachers. The questionnaire responses from the students were analyzed quantitatively by using statistical descriptive analyses. Each of students' responses were assigned to mean value 0.00 to 5.00 , ranging from very weak to very strong. The overall mean value, mode value and mode percentage of all the four aspects; questioning, providing feedback, wait time after questioning and teaching approaches were examined through descriptive test. The obtained values for each aspect informs the students' perspectives towards the two different types of teachers' actual classroom practices. Finally, the analysis of the students' questionnaire data and teachers' interview data were compared to examine the correlation of the teachers' ideologies and actual classroom practices. The analysis of teachers' interview data and learners' responses is instrumental in differentiating between the convergence and divergence of the teachers' ideologies and its implementation in actual classroom practices.

\section{FINDINGS AND DISCUSSIONS}

This section discusses the findings from the interview sessions with the teachers and the findings from the questionnaire distributed to the students. The findings from interview sessions focus on the teachers' classroom ideologies from two broad perspectives; teaching approaches and classroom discourse. Meanwhile, the findings from the students' questionnaire discusses on the actual implementation of teachers' ideologies from the students' perspectives. The findings from the questionnaire enable to compare the teachers' ideologies and its actual implementation during their teaching practices in classroom.

\section{Teacher's Teaching Approaches}

Fundamentally teaching approaches in classroom are divided into two broad types; teacher-centered and student-centered teaching style (Borg, 2003). In the teacher-centered teaching approach, teachers tend to have full authority over the lessons and students. They assert control over the teaching and learning materials, and the ways in which students study it, instruction also tends to be frontal. The transformation from conventional teaching methods to a student-centered approach has also changed the roles of the teacher and learner in the classrooms. In the student-centered style, the teachers have the primary role of facilitator. They encourage the learners to participate actively instead of just 'instructing' them, and share both decision-making and the responsibility for learning with the students; the teacher essentially just guides the learning process. The student-centered teaching style increases the learners' self-learning awareness in addition to the ordinary function of knowledge sharing. In the student-centered teaching style, the construction of knowledge is shared between the teachers and learners, and learning is achieved through the students' engagement via interactive activities (Chall, 2000) with teachers providing guidance on language learning rather than simply being the model for correct speech. Student-centered learning in ESL/EFL classrooms promotes language development use among the learners, primarily paying attention to improving communication skills (Spada, 2007). It is argued that the implementation of a student-centered teaching approach will facilitate language learning and produce proficient language users who are functional in real-life communication (Baker, 2005).

The findings from the interview sessions conducted with ETA and local Malaysian teachers revealed that both teachers somehow share the same perspective on teaching approaches. Both local and ETA teachers acknowledge the importance of a learner-centred style. They believe that a learner-centred teaching style is more communicative and achieves the ESL classroom teaching goals. However, the teachers have different perspectives on the overall use of the teaching styles. While all the native ETA firmly believe in a learner-centred style as the only and best approach in the ELT process, the Malaysian English teachers believe that other approaches such as a teacher-centred style also have their merits and can also be used along with the learner-centred teaching style. They argue that a student-centred style of teaching also means being flexible in terms of the use of different teaching approaches to accommodate to students' learning preferences.

\section{Teachers' Classroom Discourse}

The success of instruction in the language classroom is linked to the language output of the learners. In order to generate participation and engagement from the learners, the teachers need to ensure that the classroom discourse is comprehensible and appropriate for the learners. Besides the teaching styles, classroom instructions used to conduct lessons such as questioning, wait time in questioning, and corrective feedback following a response are also crucial in generating participation in the classroom. The findings from the interview sessions revealed that the teacher participants in this study strongly believe that classroom lessons should be interactive. Hence, they believe that the time given to the learners to answer a question (wait time), and the manner (type and ways) in which questions are asked and the types of feedback (implicit and explicit) appear crucial in promoting interaction among the language learners during lessons.

In most classroom contexts, learners are typically given less than a second to respond to a question asked by the teacher (Rowe, 1986). Research shows that under this condition learners are less likely to give responses that involve higher level thinking and even if there are any responses they tend to be short. Hence increasing wait time in questioning 
Table 1. Student's perceptive on native and non-native English teachers

\begin{tabular}{|c|c|c|c|}
\hline Question & Mean & Mode & Mode percentage \\
\hline \multicolumn{4}{|l|}{ Native ETA teaching pactice } \\
\hline $\begin{array}{l}\text { The ETA teaching style gives priority to the students } \\
\text { (less teacher talk and more student talk) }\end{array}$ & 4.33 & 5.00 & 53.0 \\
\hline $\begin{array}{l}\text { The ETA provides enough time for me to think and provide an answer when he/she } \\
\text { asked a question }\end{array}$ & 4.42 & 5.00 & 58.0 \\
\hline $\begin{array}{l}\text { The ETA asks more 'how and why' questions than 'what, when and who questions in } \\
\text { class }\end{array}$ & 4.24 & 5.00 & 49.0 \\
\hline The ETA corrects my mistakes immediately and it makes me to learn better. & 3.95 & 5.00 & 38.5 \\
\hline The way ETA corrects my mistakes indirectly makes me comfortable. & 4.24 & 5.00 & 47.0 \\
\hline \multicolumn{4}{|l|}{ Malaysian English teacher teaching practice } \\
\hline $\begin{array}{l}\text { Malaysian teacher teaching style gives priority to the students } \\
\text { (less teacher talk and more student talk) }\end{array}$ & 4.09 & 5.00 & 42.5 \\
\hline $\begin{array}{l}\text { The Malaysian teacher provides enough time for me to think and provide an answer } \\
\text { when he/she asked a question }\end{array}$ & 4.16 & 5.00 & 47.5 \\
\hline $\begin{array}{l}\text { The Malaysian teacher asks more 'how and why' questions than 'what, when and who } \\
\text { questions in class }\end{array}$ & 3.95 & 5.00 & 38.5 \\
\hline $\begin{array}{l}\text { The Malaysian teacher corrects my mistakes immediately and it makes me to learn } \\
\text { better. }\end{array}$ & 4.12 & 5.00 & 40.5 \\
\hline The way ETA corrects my mistakes indirectly makes me comfortable. & 4.12 & 5.00 & 53.0 \\
\hline
\end{tabular}

generates lengthier and more thoughtful responses. Both the native ETA and Malaysian English teachers shared the same belief that wait time is crucial in questioning. However, the teachers differed in relation to the amount of wait time that they feel should be given to learners. The Malaysian trained teachers prefer not to give an excessive amount of wait time to save the students' face and also because it disrupts the lessons. They argue that questions should be redirected to the next student if a learner is unable to provide an answer within a reasonable amount of time. Conversely, the native ETA are happy to give extra time in order to give everyone an opportunity to speak.

Questions are an important classroom tool in teacher-student interactions in the classroom context. Teachers make use of questions in order to initiate topics, elicit responses, test students' understanding, and generate participation (Long, 1981). All the teacher participants argued in favour of the importance of questioning in the classroom context, and also agreed on the functions and roles of questioning with respect to constructing interaction and learning opportunities in the ELT classroom context. However, they have competing sets of views in relation to the appropriateness of questioning, such as the manner in which questions are asked and the types of questions. The native ETA prefer to use open floor nomination when they ask questions in the classroom. That is, the students self-select to answer the teacher's questions. This type of nomination bears relatively low pressure for students to participate verbally. Meanwhile, the Malaysian teachers argued that individual nomination generates more participation in the classroom. They believe individual nomination helps to distribute turns fairly, enabling the teacher to test every learner's comprehension. With regard to types of questioning in the classroom, the teacher participants have varying beliefs. The Malaysian English teachers stated that they prefer to use display questions over referential questions. Display questions tend to focus on language form and have narrowly defined correct answers, whereas referential questions focus on content, have multiple answers, and also promote higher level thinking skills. In contrast, the native ETA argued that referential questions aid in communication, which is the ultimate goal of language learning. They think that display questions inhibit interactivity and critical thinking.

The term corrective feedback refers to "any reaction of the teacher which clearly transforms, disapprovingly refers to, or demands improvement of the learner utterance" (Chaudron, 1977:31). Corrective feedback facilitates language development in the ELT process. The information available in the feedback allows the learners to confirm, disconfirm, and possibly modify the hypothetical rules of their developing grammar (ibid, 1988). There are two broad types of verbal feedback in the classroom, implicit and explicit feedback. In the case of "implicit feedback, there is no overt indicator given that an error has been committed, whereas in explicit feedback types, there is" (Ellis et al. 2006:341). The native ETA suggested that implicit rather than explicit feedback is an efficient tool in correcting learners' mistakes. Although they claimed that corrective feedback is an essential learning tool, they dislike explicit feedback because it might prove to be a source of shame and embarrassment for the learners and thus end up being ineffective. Meanwhile the local teachers believe that explicit feedback is efficient if it involves a repair strategy. They remarked that students need to be aware of the existence of errors and explicit feedback serves this purpose. They believed that an explicit corrective strategy is more productive than an implicit approach, particularly for low proficiency students as in their schools.

This section discussed the ETA and local Malaysian English teachers ideologies with regard to the language 
learning and teaching process, particularly from the teaching approaches and classroom discourse perspectives. It discussed the views of the two different types of teacher participants in Malaysian classroom context regarding teacher-centered and learner centered teaching styles, types and ways questions in which questions and feedbacks are asked and provided and also wait time given after a question is asked. Overall, the ideologies of these teachers from the aspects examined revealed that they held different beliefs with respect to certain aspects of their classroom practice.

\section{Students' Perspectives on Teachers' Classroom Practices}

The objective of the second section of the questionnaire was to examine do the native ETA and Malaysian English teachers pursue different teaching practices in classroom. To answer this question, descriptive statistics were conducted on two sections in the questionnaire: student perspective on native ETA and Malaysian English teachers classroom perspectives. Then, the overall mean for both sections are compared. The items on this section were devised based on the interview questions conducted with the teacher participants. It focuses on the same aspects of classroom ideologies of the teachers.

Based on the result on table 2, participants' perceptive towards the native ETA teaching practice is stronger compared to Malaysian English teacher with an overall mean value of $4.38>4.12$ respectively. Perceptive towards the native ETA had the strongest impact from 'wait time after questioning' aspect with mean value of 4.42 . On the other hand, the weakest aspect is 'corrects my mistakes immediately, helps me to learn better' with 3.95. Four questions out of five questions in this section scored mean value more than 4.00 , which means the respondents have a strong positive perspective on native ETA teaching practice.

Meanwhile on the perspective on Malaysian English teachers, the factor that had the strongest impression was also 'wait time after questioning' with 4.16. On contrary, the weakest aspect is 'ask more how and why questions that what, when and who questions' with mean value of 3.95. Four out of five questions in this section scored mean value more than 4.00, while one question scored below 4.00. The result indicates participants have a positive perspective on Malaysian English teachers teaching practice.

Overall, participants perceptive towards native ETA teaching practice is stronger in four aspects compared to Malaysian teacher: (1) student-centered teaching style, (2) longer wait time and (3) referential questions and (4) implicit corrective strategy. The one aspect where Malaysian teacher scored higher mean values is; (1) explicit corrective feedback, helps to learn better in class. Therefore, it can be concluded that participants have a positive perceptive towards both native ETA and Malaysian English teachers teaching practice. However, the intensity is higher towards native
ETA teaching practice which can be explained by the higher overall mean value.

\section{Comparison of Teachers' Ideologies and its Actual Implementation in Classroom}

Results from the data analysis revealed that the teachers and learners have both similar and competing sets of beliefs in different aspects of ELT practices. Two generalizations emerge from the comparison of the different set of participants. First, the native ETA preferred a top down approach in their practices, as they showed preferences for open floor questioning and implicit feedback in which they prefer to provide relevant information for the learners' to repair their inaccurate responses over directly pointing it out. Similarly, they also preferred to use an open turn regulation approach. In contrast, the Malaysian English teachers preferred an approach that makes direct connection to the learners' inaccurate responses of learners. Second, the Malaysian English teachers exhibited concerns for local politeness norms. They argued that excessive wait time not only disturbs the lesson, but may also threaten learners' positive face and thus undermine learners' future participation in lessons. Meanwhile, the native ETA were less concerned with this issue. Contrary to some of the teachers, the students felt that the teachers should allocate more wait time and claimed that explicit feedback/repair is more helpful than implicit feedback.

The findings indicated that, despite several years of teaching, both sets of teachers appeared to be unaware of the discrepancies between their ideologies and actual teaching practices, regardless of the teachers' training and language backgrounds. Although studies (Lockhart, 1994; Schulz, 2001) have suggested that discrepancies between teachers' beliefs and practices can arise due to different social, environmental factors, and unanticipated events in lessons, essentially it is crucial for teachers to ensure that their ideologies and actual practices correspond. This is because prominent conflicts of ideologies and practices may impinge on the teaching and learning process. For instance, teachers may believe that they are implementing their pedagogical beliefs effectively in practice; however in the circumstance that teacher are unaware of the contradictions between their ideologies and practices it may negatively impact on the goals of their lessons. Thus, it is essential for the teachers to ensure the consistency of their pedagogical ideologies and actual practice, in order to achieve the goals of the teaching and learning process.

\section{CONCLUSION}

This study provides an answer to the two objectives of this study; do the native ETA and non-native Malaysian English teachers pursue different teaching ideologies and do the teachers implement their ideologies in actual classroom practices.

Table 2. Students' perceptive on native and non-native English teachers overall mean

\begin{tabular}{lcc}
\hline Section & Overall mean & Mode \\
\hline Perception towards the native ETA teaching practice & 4.38 & 5.00 \\
Perception towards the Malaysian English teacher teaching practice & 4.12 & 5.00 \\
\hline
\end{tabular}


First it examined the teachers' ideologies through interviews to determine if the two types of teachers pursue different teaching ideologies. Second it explores implementation of the teachers' ideologies in classroom through the lens of students' perspectives. Third, it analyses the results from the interviews and questionnaire to determine if there are any discrepancy between the teachers' ideologies and its implementation in actual classroom practices. The findings of the study revealed there were discrepancy of ideologies and practices among the teachers. Although the divergence can be associated as a reaction to the natural occurrences of classroom context where teachers need to accommodate to the needs of the classroom, the divergence of the trained Malaysian teachers suggests teacher training should be strengthen and greater awareness should be given to avoid greater divergence between ideologies and its actual implementation in classroom. Even though the small sample of teachers involved in this study limits generalization of the findings to similar contexts, it still enables to gain an understanding into the factors that differentiate the teachers' classroom ideologies and practices. The purpose of assessing the classroom ideologies and practices of native and non-native teachers is not to determine the best practice or compare the teachers but to understand to what extend the training and experience of a teacher can influence their pedagogical decision that further impact the teaching and learning process.

\section{REFERENCES}

Ãrva, V., \& Medgyes, P. (2000). Native and non-native teachers in the classroom. System, 28(3), 355-372.

Baker, R. M. \& Dwyer, F. (2005). Effect of Instructional Strategies and Individual Differences: A Meta-Analytic Assessment. International journal of instructional media, 32(1), 69.

Barrios, D. (2002). The language of the secondary classroom. In J. N. Britton \& H. Rosen (Eds.), Language, the Learner and the School. Harmondsworth: Penguin.

Borg, S. (2003). Teacher cognition in language teaching: A review of research on what language teachers think, know, believe, and do. Language Teaching, 36(2), 81109. http://dx.doi.org/10.1016/j.system.2012.05.001

Chall, J. S. (2000). The Academic Achievement Challenge: What Really Works in the Classroom? New York: The Guilford Press.

Chaudron, C. (1977). A Descriptive Model of Discourse in the Corrective Treatment of Learners' Errors Language learning, 27(1), 29-46.

Eagleton, T. (1991). Ideology: an introduction. Cambridge: Cambridge University Press. http://dx.doi.org/10.1017/ S0008423900000731

Ellis, R., Loewen, S. \& Erlam, R. (2006). Implicit and explicit corrective feedback and the acquisition of L2 grammar. Studies in second language acquisition, 28(02), 339-368.

Farimah, G. \& Fatimah, H. (2013). Teachers' self-efficacy beliefs and their English language proficiency: A study of nonnative EFL teachers in selected language centres. Procedia-Social and Behavioural Sciences, 103, 890-899.

Farahian, M., \& Rezaee, M. (2013). A Case Study of an EFL Teacher's Type of Questions: An Investigation into
Classroom Interaction. Procedia-Social and Behavioral Sciences, 47, 161-167.

Gibson, C. \& Swan, A. (2008) In IELTS Research Reports, Vol. 8 Kuala Lumpur.

Jenkins, J. (2005). Implementing an international approach to English pronunciation: The role of teacher attitudes and identity. TESOL quarterly, 39(3), 535-543.

Jerome, C., \& Samuel, M. (2015). Teachers' beliefs and classroom practices in Malaysian ESL secondary school classroom. Paper presented in International Conference on Language Studies in Kuching, Sarawak.

Kaanta, L. (2012). Teachers` embodied allocations in instructional interaction. Classroom Discourse, 3(2), 166-186.

Kroskrity, P. V. (2010). Language ideologies in evolving perspectives. Society and language use, 7(3), 192-205. http://dx.doi.org/10.1075/hoph.7.13kro

Liao, P. (2007). Teachers' beliefs about teaching English to elementary school children. English Teaching \& Learning, 31(1), 43-76.

Lockhart, C. (1994). Reflective teaching in second language classrooms. Cambridge: Cambridge University Press.

Long, M. H. (1981). Native speaker/non-native speaker conversation in the second language classroom. Teaching and Teacher Education, 82(4), 207-225.

Nayar, P. B. (1994). Whose English is it. TESL English Journal, 1(1), 1-7.

Reves, T. \& Medgyes, P. (1994). The non-native English speaking EFL/ESL teacher's self-image: An international survey. System, 22(3), 353-367.

Rowe, M. B. (1986). Wait time: slowing down may be a way of speeding up! Journal of teacher education, 37(1), 43-50.

Samad, A.A., \& Nurusus, E. (2015). Exploring Teachers' Beliefs in Teaching Grammar. Malaysian English Language Teaching Journal, 25 (1), 23-32.

Schieffelin, B. B., Woolard, K. A. \& Kroskrity, P. V. (1998). Language ideologies: Practice and theory. New York: Oxford University Press.

Schulz, R. A. (2001). Cultural differences in student and teacher perceptions concerning the role of grammar instruction and corrective feedback: USA-Colombia. The Modern Language Journal, 85(2), 244-258.

Spada, N. (2007). Communicative language teaching. In J. Cummins \& C. Davison (Eds.), International handbook of English language teaching. New York: Springer.

Tollefson, J. W. (2000). Policy and ideology in the spread of English. In J. Kelly Hall \& W. G. Egginton (Eds.), Bilingual Education and Bilingualism. Clevedon: Multilingual Matters.

Tsui, A. \& Bunton, D. (2000). The discourse and attitudes of English language teachers in Hong Kong. World Englishes, 19(3), 287-303. http://dx.doi.org/10.1111/1467971X.00180

Tsui, A. B. \& Tollefson, J. W. (2007). Language policy, culture, and identity in Asian contexts. New Jersey: Lawrence Erlbaum Associates.

Wing, E. C. (2012). Classroom teaching skills: the research findings of the teacher education project. London: Psychology Press. 